学術論文

\title{
スキュー形状およびロータスロット数が異なるかご形誘導電動機の横流解析
}

\section{Effects of Shape of Skew and Number of Rotor Slots on Interbar Current of Squirrel-cage Induction Motor}

\author{
河瀬 順洋*1(会員), 山口 忠*1(会員), 秋山 弘毅*1, 浅井 啓史*11, 古川 智康*2, 河野 寛*2 \\ Yoshihiro KAWASE (Mem), Tadashi YAMAGUCHI (Mem), Kouki AKIYAMA, Hirofumi ASAI \\ Tomoyasu FURUKAWA, Hiroshi KAWANO
}

\begin{abstract}
In this paper, we analyzed the interbar current in the steel sheets of squirrel-cage induction motors using the 3-D parallel finite element method and clarify the influences by the difference in the shape of skew and the number of rotor slot on the interbar current.
\end{abstract}

Keywords: 3-D finite element method, squirrel-cage induction motor, interbar current, skew

(2016 年 11 月 24 日受付，2017 年 4 月 6 日再受付，2017 年 4 月 21 日再々受付)

\section{1. 緒言}

かご形誘導電動機の二次導体が回転子の積層鋼 板との間で絶縁処理されていない場合，鋼板中に 横流が流れる[1]。横流はスキューを施すことで増 加し，その原因はスロット高調波の影響が大きい ことが報告されている[2]。これまで我々は三次元 並列有限要素法を用いて通常スキューを施したか ご形誘導電動機の横流解析を行い，通常スキュー が横流に及ぼす影響についての検討を行った $[3$, 4 ]。

本稿では，回転子に異なるタイプのスキューを 施したロータスロット数がステータスロット数に 近い值といて 45,99 のかご形誘導電動機を解析対 象とし, 三次元並列有限要素法を用いて横流解析 を行い, スキューの違いとロータスロット数の違 いが横流に及ぼす影響を明らかにする。

\section{2. 解析手法}

\section{1 有限要素法による磁界解析[5]}

渦電流を考慮した磁界解析のための基礎方程式 は, マクスウェルの電磁方程式より磁気ベクトル ポテンシャル $\boldsymbol{A}$ と電気スカラポテンシャル いて次式で表される。

ここで， $v$ は磁気抵抗率， $J_{0}$ は強制電流密度， $J_{e}$ は渦電流密度， $\sigma$ は導電率である。

連絡先： 河瀬 順洋, 干501-1193 岐阜市柳戸 1-1, 岐阜 大学 工学部 電気電子・情報工学科

kawase@gifu-u.ac.jp

${ }^{* 1}$ 岐阜大学＂ ${ }^{2}$ 豊田自動織機 $\operatorname{rot}(v \operatorname{rot} \boldsymbol{A})=\boldsymbol{J}_{0}+\boldsymbol{J}_{e}$

$\boldsymbol{J}_{e}=-\sigma\left(\frac{\partial \boldsymbol{A}}{\partial t}+\operatorname{grad} \phi\right)$

$\operatorname{div} \boldsymbol{J}_{e}=0$

\section{2 電気的損失の算出方法}

本解析では，鋼板に流れる渦電流は，鋼板に対 して垂直に流れる成分がないものとして取り扱っ た。鋼板で発生する横流の波形は, 磁性体の非線 形性により正弦波でなくひずみ波となることから， 横流損 $W$ は渦電流密度 $\boldsymbol{J}_{e}$ を用いて次式で計算する $[2]$ 。

$$
W=\frac{1}{\tau} \int_{t}^{t+\tau}\left(\int_{V_{e}} \frac{\left|\boldsymbol{J}_{e}\right|^{2}}{\sigma^{*}} d v\right) d t
$$

ここで， $\tau$ はひずタ波の周期， $V_{e}$ は横流の流れる導 体の領域， $\boldsymbol{J}_{e}$ は渦電流密度， $\sigma^{*}$ は鋼板に垂直な方 向の導電率を 0 とした鋼板面内方向の導電率であ る。

鋼板で発生するヒステリシス損と渦電流損は, 電磁界解析によって得られた磁束密度 $\boldsymbol{B} よ り$ 近似 的に算出する[6]。

\section{3. 解析モデルと解析条件}

Fig.1 に解析モデルを, Fig.2 に二次導体を示す。 本稿では, Fig.1 で示すようにロータスロット数が 45 と 99 のかご形誘導電動機を用いてスキューを 施さない場合, 通常スキューを施す場合, $\mathrm{V}$ 形ス キューを施す場合の合計 6 通りの解析を行う。ロ 
一タスロット数はステータスロット数に近い 45 と，その 2 倍強の 99 を検討する。また，45 スロ ットモデルおよび 99 スロットモデルの二次導体 に施すスキューの角度は同じスキューの種類の場 合，おおよそ等しい值である。解析領域はモデル の周期性により周方向ではすべての場合で全体の 1/3としている。一方，軸方向の解析領域は，ス キューなしおよび V 形スキューを施す場合では, モデルの対称性により全体の $1 / 2$ とし, 通常スキ ユーを施す場合では，1/1 としている。

Fig.3 にスキュー量 $\theta$ の定義を示す。同じスロッ rotor bar primary coil

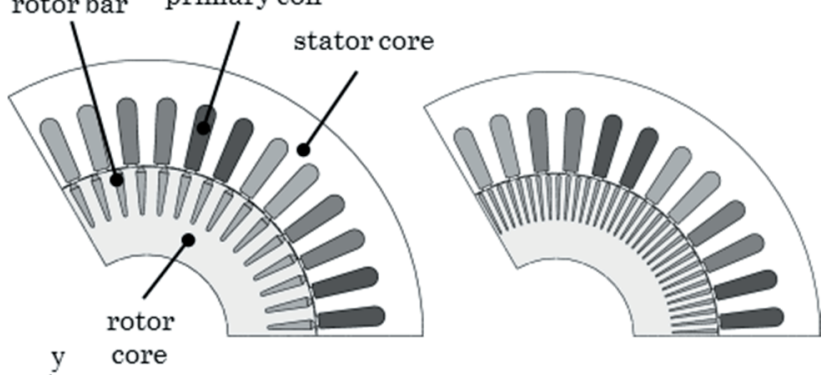

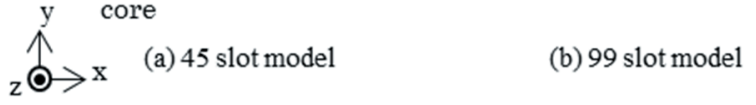

Fig. 1 Analyzed model (no-skew).
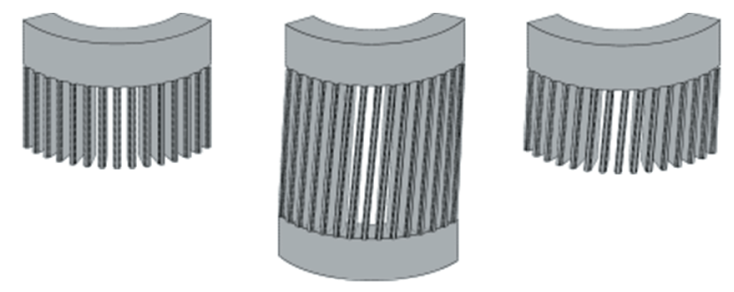

(i) no-skew

(ii) normal skew

(a) 45 slot model
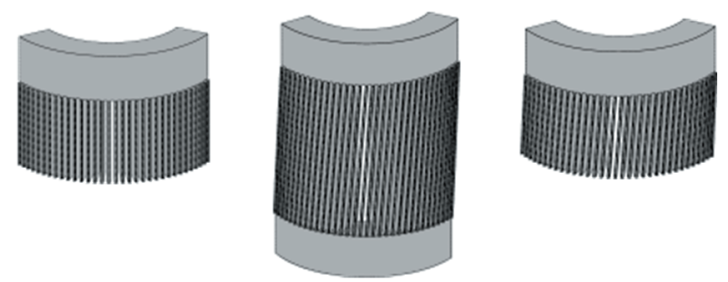

(i) no-skew

(ii) normal skew

(b) 99 slot model

(iii) V-skew

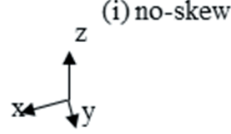

Fig. 2 Secondary conductor.

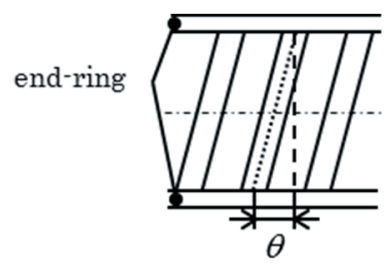

(a) normal skew

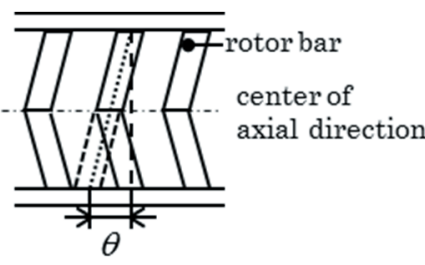

(b) V-skew
Fig. 3 Definition of skew amount.
卜数の通常スキューを施す場合のスキュー量と $\mathrm{V}$ 形スキューを施す場合のスキュー量は同じとし た。

Fig.4 に解析モデルの三次元分割図を示す。回転 子鉄心に流れる横流を求めるために回転子を構成 する鋼板 1 枚 1 枚を要素分割すると，要素数が膨 大となり多大な計算時間を要するため, 本解析で は Fig.4(b)に示すように一定間隔ごとにある鋼板 を鋼板一枚分（厚み $d$ ）で要素分割して横流を考 慮した。なお，横流を考慮した鋼板とロータスロ ットの接触抵抗は $0 \Omega$ とした。また，横流を考慮 した鋼板と鋼板の間には，厚みが鋼板の 7 枚分に 相当する鉄心があり，導電率は 0 とした。この鉄 心部分の渦電流損は磁束密度 $\boldsymbol{B}$ を用いて近似計算 している。なお，エンドリングと上端部の鋼板の 間にはギャップがあり，それらの間で渦電流が流 れることはない。なお, 図に示す鋼板 A, 鋼板 B は後述の解析結果を示声鋼板を表している。

Table 1 にモータの仕様等を示す。

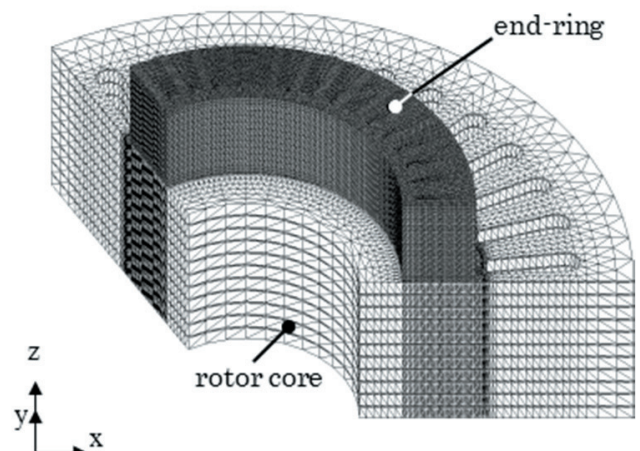

(a) birds-eye view

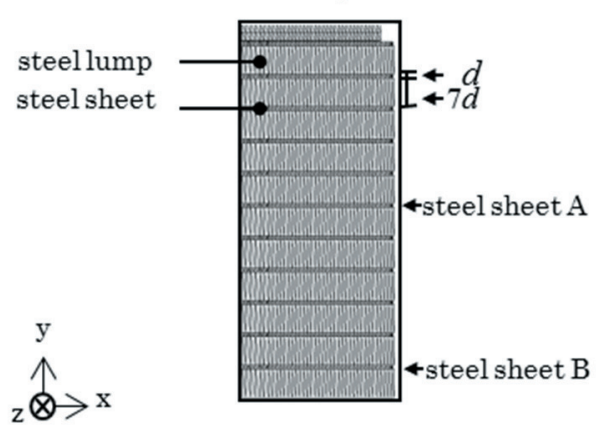

(b) sectional view of rotor core

Fig. 4 3-D finite element mesh.

Table 1 Specification of motor.

\begin{tabular}{c|c|c|c}
\hline \multicolumn{2}{c|}{ Number of rotor slots } & 45 & 99 \\
\hline \multicolumn{2}{c|}{ Skew type } & \multicolumn{2}{|c}{$\begin{array}{c}\text { no-skew } \\
\text { normal skew } \\
\text { V-skew }\end{array}$} \\
\hline \multicolumn{2}{c}{ Exciting current (AT) } & 640 \\
\hline \multirow{2}{*}{$\begin{array}{c}\text { Conductivity } \\
(\mathrm{S} / \mathrm{m})\end{array}$} & $\begin{array}{c}\text { Secondary } \\
\text { conductor }\end{array}$ & Steel sheet & $3.14 \times 10^{7}$ \\
\cline { 2 - 3 } & & $6.67 \times 10^{6}$ \\
\hline
\end{tabular}




\section{4. 解析結果と検討}

Fig.5 にトルク波形を, Table 2 にロータスロッ 卜数ごとの平均トルクとトルクリプルを示す。な お, 值は45 スロットモデルのスキューなしの平均 トルク $\left(T_{\text {ave, no-skew-45 }}\right)$ の值で正規化している。図 と表から，スキューおよびV 形スキューを施した ことで，スキューを施さない場合と比較して平均 トルクおよびトルクリプルが小さくなっているこ とがわかる。また，45 スロットモデルと比較して 99 スロットモデルではスキューを施さない場合 およびV形スキューを施した場合に平均トルクが 減少するが，スキューを施した場合では大きくな っていることがわかる。

Fig.6 に横流密度ベクトル分布を示す。図から， ロータスロット数に関わらず鋼板 A では，通常ス

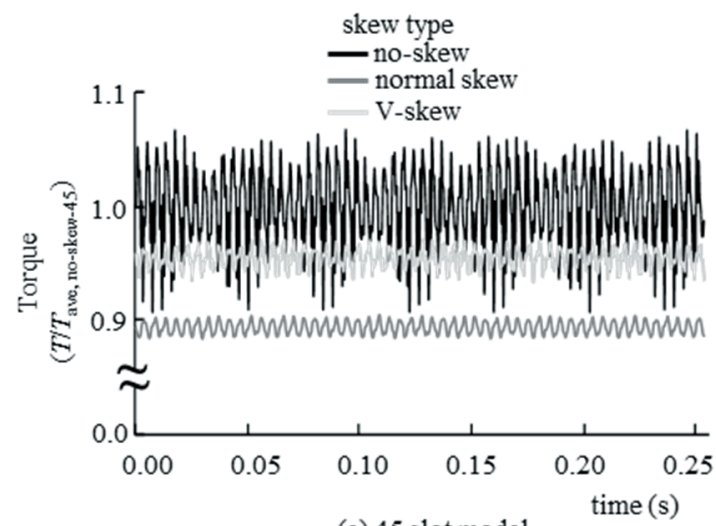

(a) 45 slot model

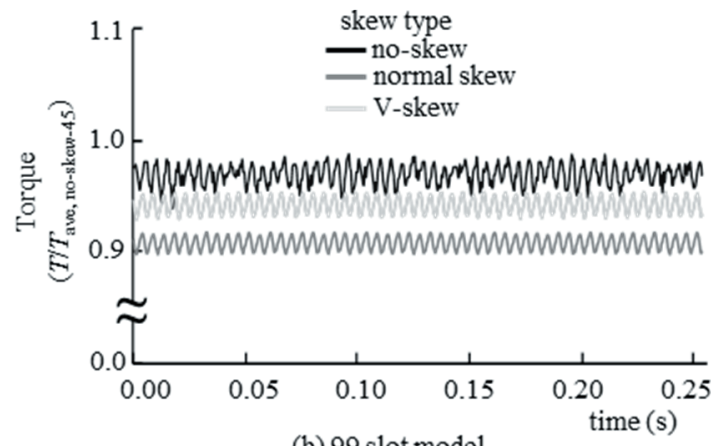

(b) 99 slot model

Fig. 5 Torque waveforms.

Table 2 Average torque and torque ripple ( $\left.T / T_{\text {ave, no-skew-45 }}\right)$

(a) 45 slot model

\begin{tabular}{c|c|c|c}
\hline Skew type & no-skew & normal skew & V-skew \\
\hline Average torque & 1.000 & 0.894 & 0.955 \\
\hline Torque ripple & 0.158 & 0.020 & 0.024 \\
\hline \multicolumn{4}{c}{ (b) 99 slot model } \\
\hline Skew type & no-skew & normal skew & V-skew \\
\hline Average torque & 0.970 & 0.908 & 0.942 \\
\hline Torque ripple & 0.048 & 0.020 & 0.024 \\
\hline
\end{tabular}

キューおよび V 形スキューを施す場合，横流が回 転子表面を流れているが，スキューを施さない場 合，ほとんど流れていないことがわかる。一方， 鋼板 B では，通常スキューを施す場合，横流は回 転子表面を流れているが，スキューなしおよび V 形スキューを施す場合，ほとんど流れていないこ とがわかる。また 45 スロットモデルと比較して 99 スロットモデルでは全ての場合で回転子表面を流 れる横流が大きくなっていることがわかる。

Fig.7 に鋼板 A および鋼板 B を流れる横流の波 形を, Fig.8 に横流の主要高調波成分を示す。図中 で示すように横流波形は隣り合うロータバーの間 を流れる横流を Pから Q までの断面で積分してい る。なお，值は 45 スロットモデルの鋼板 A での スキューなしの波形の最大值（ $I_{\max }$, steel sheet $\mathrm{A}$, no-skew-45）で正規化している。図から, ロータスロ ット数に関わらず鋼板 $\mathrm{A}$ では $\mathrm{V}$ 形スキュー, 通常 スキュー，スキューなしの順に波形に含まれるリ プル成分が小さくなることがわかる。一方，鋼板 B では通常スキューを施す場合の波形に含まれる リプル成分が大きく, スキューなしおよび V 形ス キューを施す場合の波形に含まれるリプル成分は わずかであることがわかる。これはスキューによ ってロータバーの上部と下部で固定子ティースに 対する位相差が発生し，それに伴い鋼板中の横流 の流れ方が変化したためだと考えられる。また， 45 スロットモデルと比較して 99 スロットモデル では鋼板 $\mathrm{A} の$ 波形のリプル成分が大きくなってお り鋼板 B の通常スキューを施した場合の高調波成 分の変化が小さくなっていることがわかる。

Fig.9 にロータスロット数ごとの横流損分布を 示す。なお，值は45 スロットモデルのスキューな しの各鋼板の横流損の合計值 (Loss sum, no-skew-45) で 正規化している。眓から，ロータスロット数に関 わらずスキューを施さない場合，回転子軸方向端 部に横流損が集中しているが，通常スキューおよ びV形スキューを施した場合と比較してその值は 小さいことがわかる。通常スキューを施す場合， 回転子軸方向中央部に横流損が集中していること がわかる。一方，V 形スキューを施す場合，回転 子軸方向端部と中央部の横流損が小さく, その中 間の鋼板に集中していることがわかる。これは Fig.7 に示した横流の流れ方の変化が原因である と考えられる。また 45 スロットモデルと比較して 99 スロットモデルではすべての場合で各鋼板の 横流損が大きくなっており特にV形スキューを施 した場合の横流損が大きいことがわかる。

Fig.10 に電気的損失を示す。なお，值は45 スロ ットモデルのスキューなしの電気的損失の合計值 


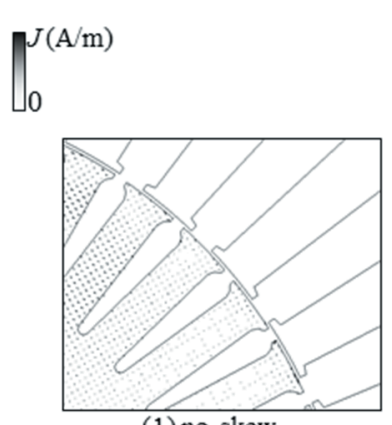

(1) no-skew

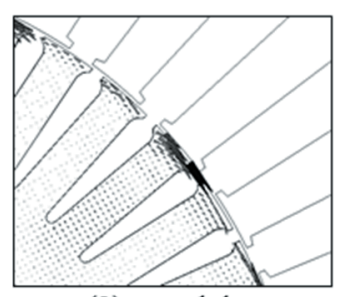

(2) normal skew

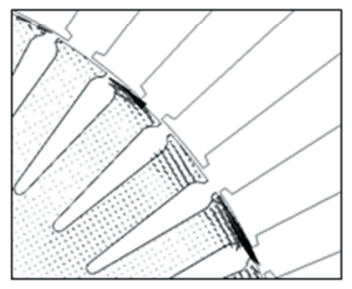

(3) V-skew

(i) steel sheet $A$

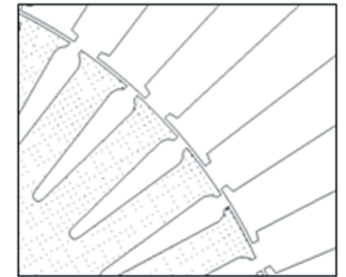

(1) no-skew

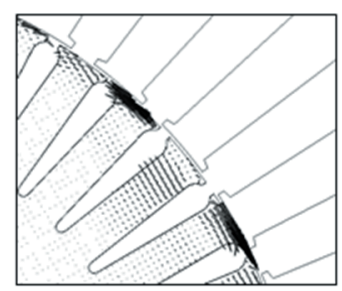

(2) normal skew

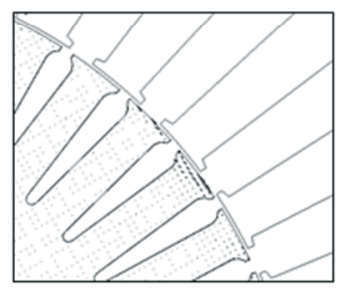

(ii) steel sheet $B$
(3) V-skew

(a) 45 slot model

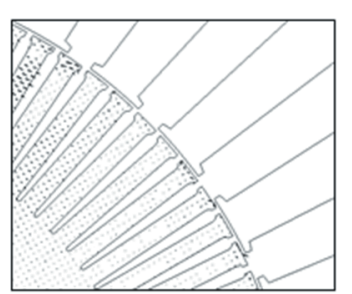

(1) no-skew

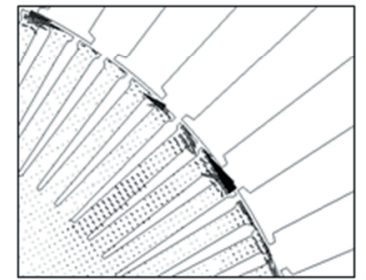

(2) normal skew

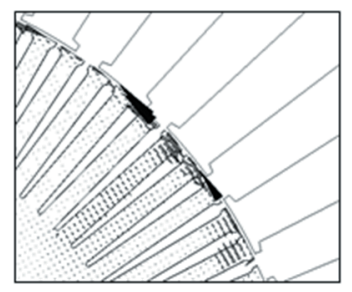

(3) V-skew

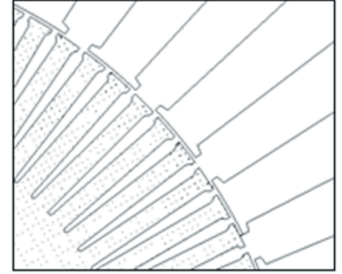

(1) no-skew

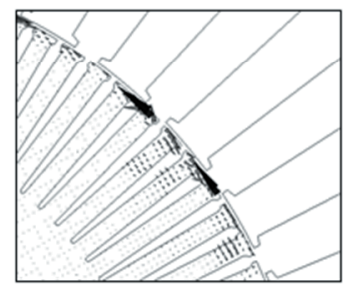

(2) normal skew

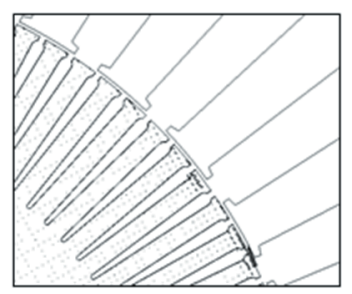

(3) V-skew

(ii) steel sheet $B$

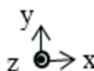

(i) steel sheet $\mathrm{A}$

(b) 99 slot model

Fig. 6 Distributions of interbar current density vectors.

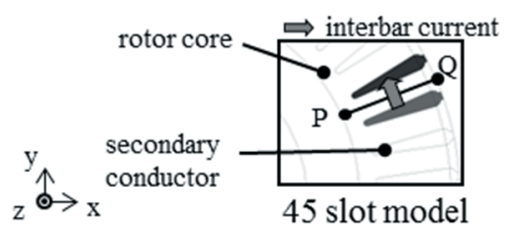

*calculating plane in Fig. 7(a)

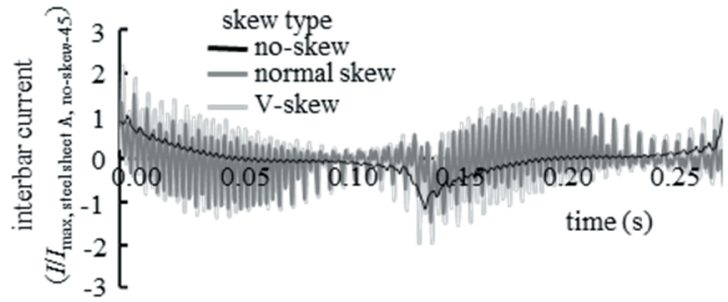

(i) steel sheet $\mathrm{A}$

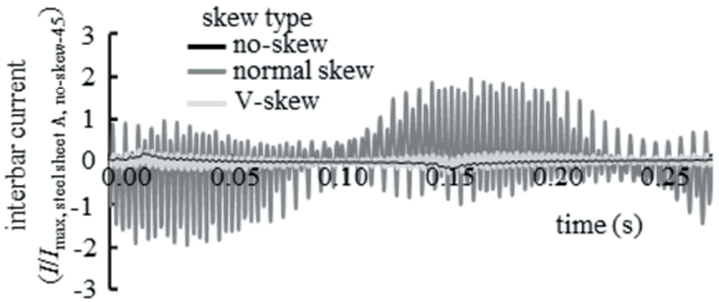

(ii) steel sheet $B$

(a) 45 slot model

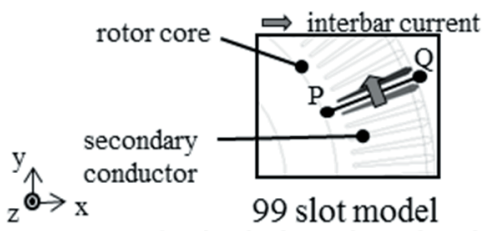

*calculating plane in Fig. 7(b)

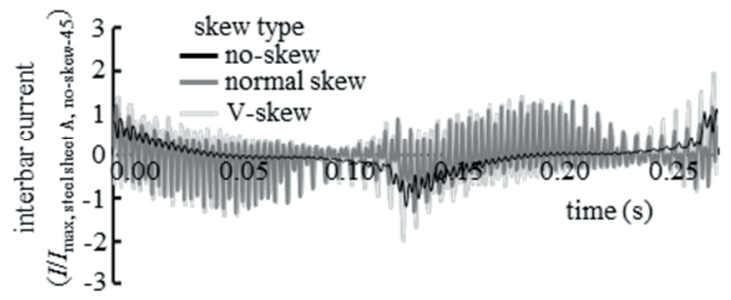

(i) steel sheet $A$

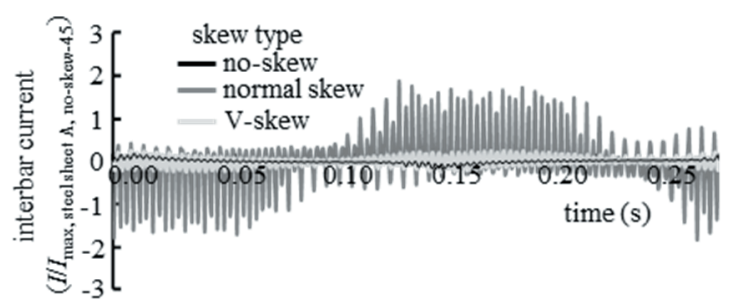

(ii) steel sheetB

(a) 99 slot model

Fig. 7 Interbar current waveforms. 


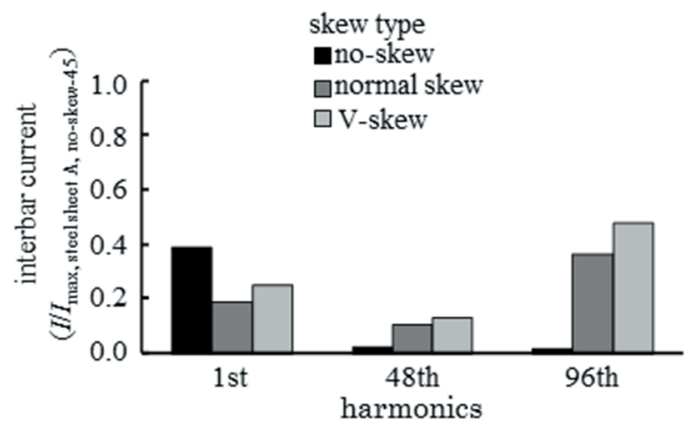

(i) steel sheet $\mathrm{A}$

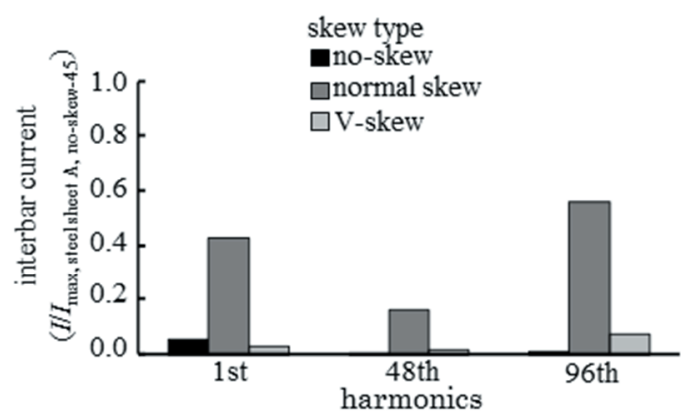

(ii) steel sheetB

(a) 45 slot model

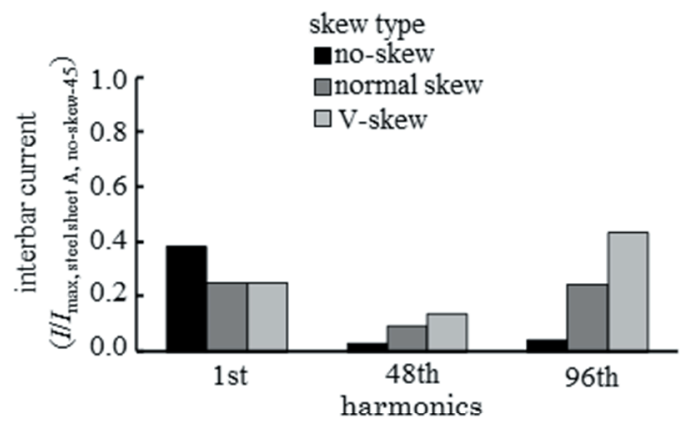

(i) steel sheet $\mathrm{A}$

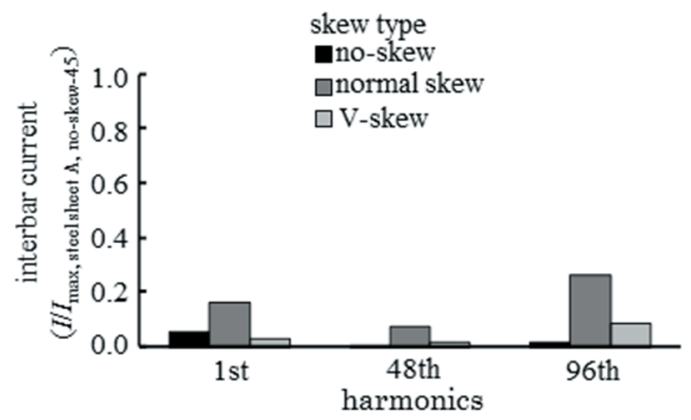

(ii) steel sheet $B$

(b) 99 slot model

Fig. 8 Main harmonic components.
( Loss $\left._{\text {total, no-skew-45 }}\right)$ で正規化している。Fig.10(a)か ら，45 スロットモデルの場合スキューを施さない 場合と比較して通常スキューを施したモデルの二 次銅損はおよそ $83.7 \%$, V 形スキューを施したモ デルはおよそ $92.6 \%$ となっていることがわかる。 また，通常スキューを施したモデルの横流損はス キューを施さない場合と比較しておよそ 8.8 倍, $\mathrm{V}$ 形スキューを施したモデルはおよそ 6.7 倍となっ ていることがわかる。また，45 スロットモデルと 比較して Fig.10(b)の 99 スロットモデルの横流損 はスキューを施さない場合および通常スキューの 場合およそ 1.2 倍, $\mathrm{V}$ 形スキューの場合およそ 1.3 倍となっていることがわかる。

Table 3 に解析諸元を示寸。

\section{5. 結言}

本稿では，回転子にVV形スキューを施したロー タスロット数が 45 と 99 のかご形誘導電動機を解 析対象とし，三次元並列有限要素法を用いて横流 解析を行い，スキューの違いとロータスロット数 の違いが横流に及ぼす影響を明らかにした。その 結果，ロータスロット数に関わらず通常スキュー を施すことで回転子軸方向中央部に集中していた 横流損が，V 形スキューを施したことで回転子軸 方向端部と中央部の中間に集中することがわかっ た。これはスキューによってロータバーの上部と 下部で固定子ティースに対する位相差が発生し, それに伴い鋼板中の横流の流れ方が変化したため だと考えられる。また 45 スロットモデルと比較し て 99 ロータスロットモデルでは各鋼板の横流損 がすべてのスキューの場合で大きくなっているこ とがわかった。

\section{参考文献}

[1]「誘導機と同期機の損失評価技術」, 電学技法 No.967, 2004. (in Japanese)

[2] 山崎克巳, 渡辺裕太 : 「三次元有限要素法による誘 導電動機の横流解析に関する検討」, 電気学会回転 機研究会資料，RM-04-113，pp.95-100, 2004.

[3] 河瀬順洋, 山口忠, 岩井良樹, 樋田直孝, 古川智 康 :「三次元並列有限要素法によるスキューを施し たかご形誘導電動機の横流解析」, 電気学会静止 器・回転機研究会資料, RM-14-106/SA-14-90, pp.57-60, 2014.

[4] 河瀬順洋, 山口忠, 岩井良樹, 秋山弘毅, 樋田直 孝, 古川智康 : 「かご形誘導電動機のロータスロッ 卜数が横流へ及ぼす影響の検討」, 電気学会静止 器・回転機研究会資料, RM-15-46/SA-15-54, pp.123-126, 2015. 
[5] 伊藤昭吉・河瀬順洋 :「最新有限要素法による電気・ 電子機器の $\mathrm{CAE} 」$, 森北出版, 2000

[6] 山崎克巳:「固定子及び回転子の高調波磁界を考慮し た誘導電動機の損失算定」, 電気学会論文誌 D, vol.123, no.4, pp.392-400, 2003.
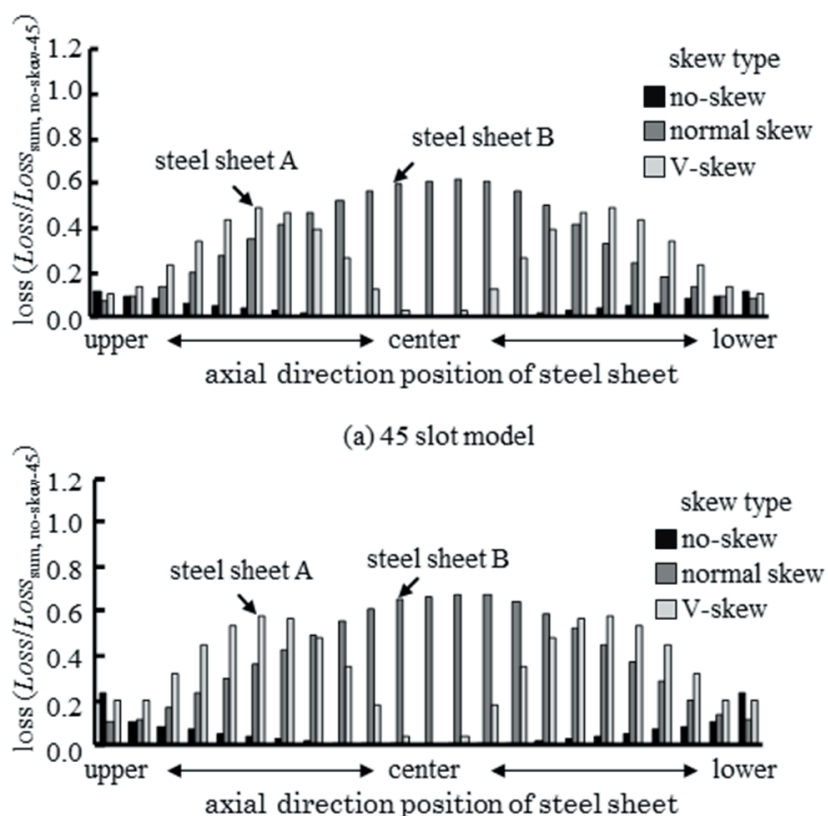

(b) 99 slot model

Fig. 9. Distributions of interbar current loss.

Table 3 Discretization data and elapsed time (a) 45 slot model

\begin{tabular}{|c|c|c|c|}
\hline Skew type & no-skew & $\begin{array}{c}\text { normal } \\
\text { skew }\end{array}$ & V-skew \\
\hline Number of elements & $2,568,390$ & $5,201,208$ & $2,568,390$ \\
\hline Number of nodes & 441,672 & 884,136 & 441,672 \\
\hline Number of edges & $3,037,023$ & $6,119,539$ & $3,037,023$ \\
\hline Total number of time steps & 1,067 & \multicolumn{2}{|c|}{1,600} \\
\hline Elapsed time (hours) & $190.8^{* 1}$ & $464.8^{* 2}$ & $304.9^{* 3}$ \\
\hline & Compute & $\begin{array}{l}\text { d: }{ }^{* 1} \text { Intel Cor } \\
{ }^{* 2} \text { Intel Cor } \\
{ }^{* 3} \text { Intel Xe }\end{array}$ & $\begin{array}{l}(3.4 \mathrm{GHz}) \times \\
(3.4 \mathrm{GHz}) \times 1 \\
(3.5 \mathrm{GHz}) \times 1\end{array}$ \\
\hline
\end{tabular}

(b) 99 slot model

\begin{tabular}{|c|c|c|c|}
\hline Skew type & no-skew & $\begin{array}{c}\text { normal } \\
\text { skew }\end{array}$ & V-skew \\
\hline Number of elements & $3,814,014$ & $7,721,424$ & $3,814,014$ \\
\hline Number of nodes & 654,984 & $1,309,264$ & 654,984 \\
\hline Number of edges & $4,507,335$ & $9,075,061$ & $4,507,335$ \\
\hline Total number of time steps & 1,067 & \multicolumn{2}{|c|}{1,600} \\
\hline Elapsed time (hours) & $184.5^{* 1}$ & $584.9^{* 2}$ & $325.1^{* 3}$ \\
\hline
\end{tabular}

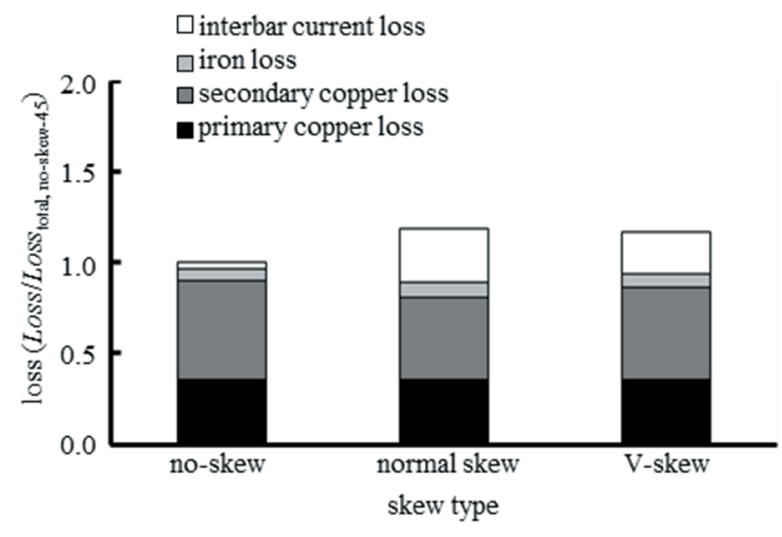

(a) 45 slot model

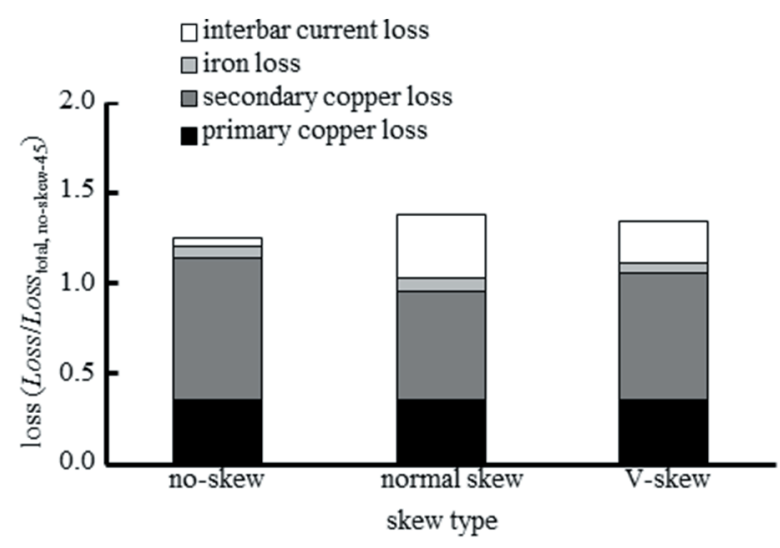

(b) 99 slot model

Fig. 10 Electrical loss. 